\title{
Reliability of roof structures subjected to snow loads
}

\author{
Pietro Croce, Paolo Formichi, Filippo Landi \\ Department of Civil and Industrial Engineering, Structural Division, University of Pisa, Pisa, Italy. E-mail: \\ p.croce@ing.unipi.it
}

\begin{abstract}
A proper evaluation of snow loads on roofs is crucial for structural design especially to guarantee an adequate reliability level of lightweight roof structures. The definition of roof snow load in structural codes is based on both the evaluation of ground snow loads and conversion factors from ground to roof load, which are function of the roof's geometry, its exposure to wind and its thermal properties. However, reference values of roof snow loads are based only on an extreme value analysis carried out to derive characteristic values of ground snow load, while conversion factors are considered as deterministic quantities due to the lack of the data.

In this paper, first a methodology to evaluate the reference value of roof snow load is presented based on the definition of probability density functions for ground snow loads and conversion factors accounting for roof's geometry and its exposure to wind. The results lead to the definition of a design conversion factor which depend on the coefficient of variation of ground snow loads and are compared with the constant values provided by the Eurocode models, in EN1991-1-3:2003. Then, structural reliability is assessed for reference steel and timber structures located in different sites. Considering different proportions between variable and permanent loads, the reliability of flat roofs designed according to Eurocode provisions, provided by the current version and the new draft, is finally compared with the required target reliability levels.
\end{abstract}

Keywords: Snow Load, Shape Coefficient, Eurocodes, Reliability.

\section{Introduction}

The collapse of roof structures under extreme snow loads can have catastrophic consequences as it is confirmed by the recent failures of largespan lightweight structures occurred in Europe (Croce et al. 2018a, Croce et al. 2018b).

A proper evaluation of snow load is thus crucial for design of roofs and after the collapses of a considerable number of roofs during the winter period 2005/2006 a discussion on the reliability of roofs exposed to snow load was initiated (Holicky 2007) (Sykora and Holicky, 2008).

In particular, it has been questioned that the partial factor design method provided in the present European standards may not guarantee an adequate reliability level for lightweight roofs (Holicky 2007), which are characterized by a high ratio between variable and permanent loads.

Roof snow loads given by modern building codes for structural design are based on the probabilistic estimations of ground snow loads (Kozak and Liel, 2015) while conversion factors from ground to roof snow load are only seldom based on statistical considerations, also due to the lack of data and to the complexity of the problem. Therefore, the design roof snow load is obtained by multiplying the reference value of ground snow load characterized by a low probability of exceedance, e.g. $p=0.02$ in one year in Europe according to EN1990 (CEN, 2002), by a deterministic value of ground to-roof conversion factor that depends on the roof's exposure, slope, and thermal conditions. This factor, which can vary between 0.4 and 1.1 (Kozak and Liel, 2015), is characterized by high variability and should be considered in establishing design loads for roofs (Ellingwood and O'Rourke, 1985). However, since the available measurements are very limited, design values of roof conversion factors, which are given in codes, are not determined on statically basis but mainly refer to conservative values based on engineering judgement. Generally, considering only ground snow load as a random variable, the resulting roof snow load will not have the same probability of exceedance of the ground snow loads.

A first attempt to derive design conversion based on a probabilistic approach can be found in (O'Rourke, 1983) (Ellingwood and O'Rourke, 1985) for the US. Log-Normal distribution were considered for both ground snow load and conversion factor and design conversion factors were presented for 128 sites in the US (O'Rourke, 1983). To the author's knowledge, no similar study are available for Europe, where extreme value distribution is commonly adopted for ground snow load (Sanpaolesi et al. 1998) (Croce et al., 2019b).

Therefore, first, a methodology to evaluate the reference value of roof snow load is presented taking into account both the uncertainty in ground snow load and conversion factors. Joint probability density functions are determined and the resulting design conversion factors are 
defined in order to obtain a value of roof snow load consistent with the probability of exceedance of ground snow load. Since design conversion factors depend also on the uncertainty associated to ground snow load, useful curves for the derivation of design conversion factors based on the coefficient of variation of ground snow loads will be presented.

Finally, the reliability level of flat roof designed according to Eurocode provisions is evaluated, starting from the probabilistic models for ground snow load and conversion factors discussed in the paper.

\section{Probabilistic description of roof snow load}

Snow load on roofs is defined in EN1991-13:2003 (CEN, 2003) as:

$$
s=\mu_{i} C_{e} C_{t} s_{g, k}
$$

where

$S_{\mathrm{g}, \mathrm{k}}$ is the characteristic value (probability of exceedance $p=0.02$ in one year) of ground snow load;

$\mu_{\mathrm{i}}$ is the snow load shape coefficient, depending on the roof's geometry (e.g., flat, pitched or curved roofs);

$C_{\mathrm{e}}$ is the exposure coefficient, which defines the reduction or increase of load on a roof of an unheated building due to the roof exposure to wind.

$C_{\mathrm{t}}$ is the thermal coefficient, to take account of the effects of heat flux through the roof, which, in general, results in a reduction of the roof load.

The shape coefficient $\mu_{\mathrm{i}}$ can be considered also a function of the exposure of the site according to (Thiis and O'Rourke, 2015). Therefore, a new formulation of $\mu_{\mathrm{i}}$ depending on $C_{\mathrm{e}}$ has been proposed in the new draft of prEN1991-1-3:2019.

Assuming the thermal coefficient as a deterministic quantity, roof snow load is the product of two random variables, the shape coefficient (or conversion factor which depends on the exposure of the site) and the ground snow load.

\subsection{Ground snow load}

Ground snow load is the basic information needed for the determination of snow load on structures to be used for structural design (Croce et al., 2019b). Characteristic load values are estimated starting from the extreme value statistical analysis of snow water equivalent data, or snow depth measurements supplemented by a snow density model, under the assumption of stationary climate (Croce et al. 2018a).

The choice of the proper distribution to characterize extreme snow loads should depend on the different climate conditions, the most widely used is the Gumbel distribution, which was adopted for the development of maps presented in Annex C to EN1991-1-3:2003 (Sanpaolesi et al., 1998). Characteristic values of ground snow load, $s_{\mathrm{g}, \mathrm{k}}$, are then reported in climatic load maps to provide load values at any potential construction site within a given region. Generally maps include ground snow loads reduced at sea level and snow load altitude relationships are defined as a function of the climatic features of a given region. A critical review of the current definition of snow load maps in structural codes can be found in (Croce et al., 2019b).

\subsection{Roof conversion factors}

Although data on ground snow loads have been collected and extensively studied in the last years for the whole European territory (Sanpaolesi et al. 1998) (Croce et al., 2019b), less information is available for the shape coefficients $\mu_{\mathrm{i}}$, also known as "conversion factor" $c$ from ground to roof snow load (O'Rourke, 1983). Conversion factors depend upon the roof's geometry, the exposure of the site, i.e. the location of the roof relative to its surroundings (O'Rourke et al., 1982) and the wind conditions. Three different conditions are commonly defined depending on the shelter effect induced by trees, buildings and other obstructions on the investigated roofs: sheltered roof, semi-sheltered roof (normal condition) and windswept roof (exposed condition).

Measurements of roof snow loads were collected and reported in (O'Rourke et al., 1982) and (O'Rourke, 1983) for the US, to establish a suitable probability density function for roof snow loads. In these papers appropriate coefficients were derived to be used in structural codes to obtain the characteristic value of roof snow loads directly from the characteristic value of ground snow loads.

For Europe data were collected, during the European Snow Load Research Project and reported in (Sanpaolesi et al., 1999), in Switzerland, Italy, United Kingdom and Germany. A significant database of nearly 1300 measurements of snow load on roof was collected by Høibø (Høibø , 1988) (Høibø, 1989) on more than 200 agricultural buildings in Norway for the period 1966-1986. These data, described in (Thiis and O'Rourke 2015), were used for the definition of a new model for gable roof, which is being proposed in the new draft of prEN1991-1-3:2019.

Roof conversion factors for European regions, US and Norway are compared in Table 1 for flat roofs in different exposure conditions.

European values are generally, higher than American ones, while coefficients of variation 
are smaller. Norwegian values are instead characterized by lower values of coefficient of variation.

Table 1. Roof conversion factors for flat roofs in sheltered, normal and exposed conditions.

\begin{tabular}{lcccccc}
\hline \multicolumn{1}{c}{ Site } \\
Exposure & U.S. (O’Rourke & $\begin{array}{c}\text { Europe } \\
\text { et al., 1983) }\end{array}$ & \multicolumn{3}{c}{$\begin{array}{c}\text { Norway } \\
\text { (Thiis and } \\
\text { et al., 1999) }\end{array}$} & \multicolumn{2}{c}{$\begin{array}{c}\text { O'Rourke, } \\
\text { 2015) }\end{array}$} \\
& Mean & $\sigma$ & Mean & $\sigma$ & Mean & $\sigma$ \\
\hline Sheltered & 0.83 & 0.36 & 0.90 & 0.08 & 0.75 & 0.12 \\
Normal & 0.63 & 0.27 & 0.74 & 0.29 & 0.66 & 0.11 \\
Exposed & 0.60 & 0.26 & 0.58 & 0.19 & - & - \\
\hline
\end{tabular}

A Log-Normal distribution can be adopted for the conversion factors in Europe as it was already done in (O'Rourke, 1983) for the US data.

\section{Evaluation of design roof conversion factor}

As mentioned above, roof snow load can be considered as the product of two random variables, the ground snow load $S_{\mathrm{g}}$ and the conversion factor $c$. Therefore, the probability distribution function for annual maximum roof snow load can be derived as the product of the two marginal $p d f s$ assuming independence.

$$
f_{S}(s)=f_{s_{g}}(s) f_{c}(c)
$$

In Fig. 1, an example of joint $p d f$ is reported for an Italian weather station, Lodi (80 $\mathrm{m}$ a.s.1.), assuming normal exposure of the site $(\bar{c}=0.74$ and $\sigma_{\mathrm{c}}=0.29$ according to Table 1 ).

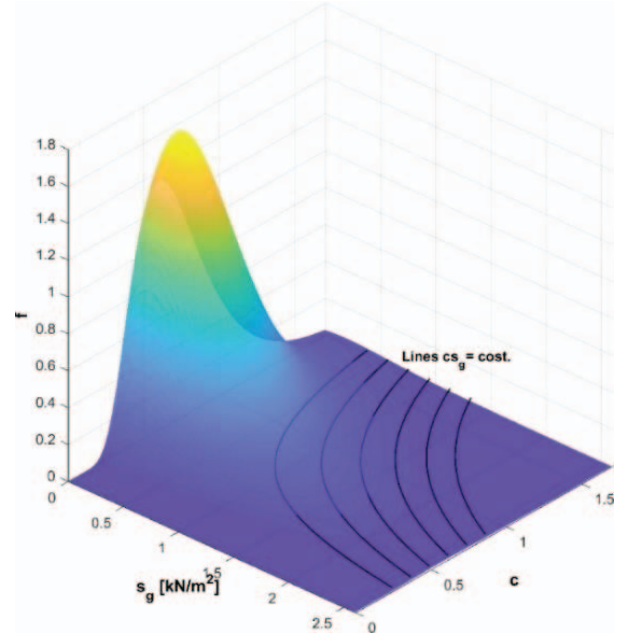

Fig. 1. Joint $P D F$ of ground snow load $s_{g}$ and conversion factor $c$, Lodi weather station and normal exposure of the site.
Then, the probability that a given value of roof snow load $s$ is exceeded can be computed as

$$
F_{S}(s)=\int_{-\infty}^{s}\left[\int_{-\infty}^{\infty} f_{S}\left(c, \frac{s}{c}\right) \frac{1}{c} d c\right] d s
$$

which consists in the calculation of the volume under the region delimited by the vertical sectional area under the joint $p d f$ (Cook and Mayne, 1980) along the curved lines of constant $s$, black lines in Fig. 1.

The integral in Eq. (3) can be computed by using the Monte Carlo method. Since we are interested in the derivation of the roof snow load $s_{k}$ associated to a probability of exceedance $p$ in one year ( $p=0.02$ according EN1990), the following procedure can be followed:

- an high number of samples is generated $\left(\mathrm{N}=10^{8}\right)$ according to the $p d f s$ for ground snow loads $s_{\mathrm{g}, \mathrm{i}}$ and shape coefficient $c_{i}$, then samples for roof snow loads $s_{i}$ are obtained by multiplying them;

- the empirical 1- $p$ - quantile, representing the characteristic roof snow load, $s_{\mathrm{k}}$, is computed from the generated samples.

Once obtained the characteristic roof snow load $s_{\mathrm{k}}$, the design shape coefficient can be determined as the ratio between $s_{\mathrm{k}}$ and the characteristic ground snow load $s_{\mathrm{g}, \mathrm{k}}$

$$
\mu_{d} \text { or } c_{d}=\frac{s_{k}}{s_{g, k}}
$$

In order to take a broad view of the results characterizing different weather stations and exposure conditions, curves for design values of roof shape coefficients can be derived depending on the coefficient of variation of annual maxima ground snow load, $\mathrm{COV}_{\mathrm{g}}$.

Curves for the design values of roof shape coefficients are plotted in Fig. 2 for flat roofs in the three possible exposure conditions (sheltered in green, normal in blue and exposed in red) as a function of the coefficient of variation $\left(\mathrm{COV}_{\mathrm{g}}\right)$ of the annual maxima ground snow load.

The investigated range for $\mathrm{COV}_{\mathrm{g}}$ is chosen to cover the possible variation of this parameter for ground snow load; in fact, the theoretical curves in Fig.2 are supplemented by point values corresponding to data from 25 Italian weather stations located in lowland, medium altitude and mountain regions, and assuming the three different three different exposure conditions.

The dashed lines representing the variability of the conversion factor $c_{\mathrm{d}}$ are compared with the 
constant values given in EN1991-1-3:2003 (solid lines).

Finally, in the Fig. 2, the probabilities of exceedance associated to the extremes of the investigated range for $\mathrm{COV}_{\mathrm{g}}$, which are obtained by using the Eurocode model, are also reported. If normal exposure is considered, the estimated probability of exceedance of the roof snow load, determined by means of the Eurocode provisions, can vary between 0.046 and 0.024 , while for exposed conditions it can vary between 0.037 and 0.019 .

It is worth noting that the design shape coefficient is almost constant in case of sheltered conditions due to the low coefficient of variation associated to the measured conversion factors, with a corresponding probability of exceedance of 0.015 in one year.

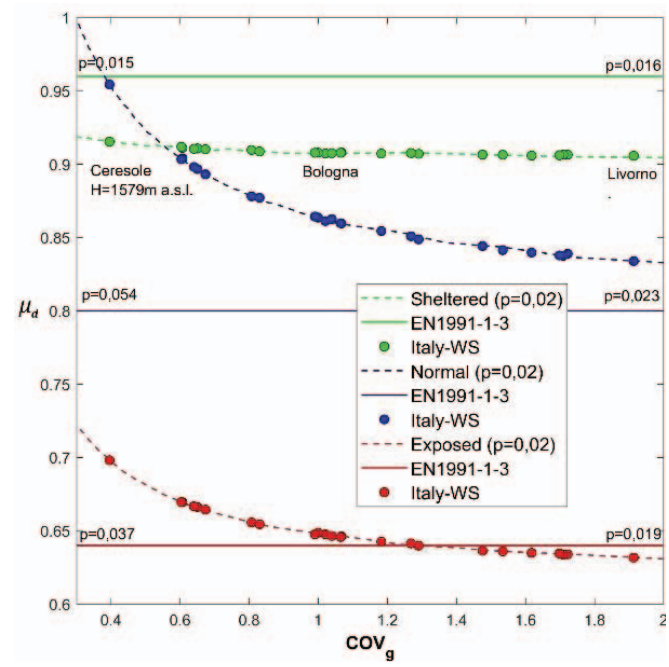

Fig. 2. Design conversion factor for flat roofs, $c_{\mathrm{d}}$, dependence with the coefficient of variation of annual maxima ground snow load $\left(\mathrm{COV}_{\mathrm{g}}\right)$ and exposure conditions.

\section{Reliability analysis of roof structures}

The reliability of roofs designed in accordance with principles in EN1990 and EN1991-1-3 has been evaluated. In the following the snow load is labelled as $Q$, in accordance with the general notation in EN1990 for variable actions. A generic linear limit state function is defined considering that the failure mode is dominated by a material property $R_{\mathrm{i}}$ and the loads are the effects of the permanent load $G$, and the snow load $Q$

$$
g\left(X, p_{i j}\right)=p_{i} \Theta_{R, i} R_{i}-\left(G+\Theta_{Q} Q\right)
$$

where

$\theta_{R, i}$ is the resistance model uncertainty for the material property $i$

$\theta_{Q}$ is the snow time invariant part considering both model uncertainty and shape coefficient;

$p_{i}$ is the design variable which is determined by the design equations of EN 1990 for the material property $i$, e.g. considering load combination 6.10

$$
p_{i j}=\frac{\gamma_{M, i}}{\theta_{R i, k} R_{i, k}}\left\{\gamma_{G} G_{k}+\gamma_{Q} \theta_{Q k} Q_{k}\right\}
$$

with $\gamma_{\mathrm{G}}=1.35$ and $\gamma_{\mathrm{Q}}=1.5$, while $\gamma_{\mathrm{M}, \mathrm{i}}$ is the partial safety factor for the material property $i$ and $\theta_{O K}$ are the conversion factors given in EN1991-1-3 for the different exposure conditions ( 0.96 for sheltered conditions, 0.8 for normal condition and 0.64 for exposed condition).

The load ratio is given as the fraction of the characteristic value of the snow load on the roof over the total characteristic load

$$
\chi=\frac{Q_{k}}{Q_{k}+G_{k}}
$$

A realistic range from 0.2 to 0.8 of the load ratio $\chi$ is considered (Gulvanessian and Holicky, 2008) (Sykora and Holicky, 2008).

In the following reliability analysis, steel, glulam timber and solid timber structures have been investigated and the stochastic models reported in Table 2 have been adopted based on the JCSS model code (JCSS, 2001).

\begin{tabular}{|c|c|c|c|c|}
\hline Variable & Mean & $\mathrm{COV}$ & PDF & $\gamma$ \\
\hline $\begin{array}{l}\text { Resistance } \\
\text { model unc.(steel) }\end{array}$ & $\theta_{R \mathrm{k}}$ & 0.05 & $\mathrm{LN}$ & - \\
\hline $\begin{array}{l}\text { Steel yielding } \\
\text { strength }\end{array}$ & $R_{k}+2 \sigma$ & 0.07 & $\mathrm{LN}$ & 1.00 \\
\hline $\begin{array}{l}\text { Resistance } \\
\text { model } \\
\text { unc.(glulam) }\end{array}$ & $\theta_{R \mathrm{k}}$ & 0.10 & $\mathrm{LN}$ & - \\
\hline $\begin{array}{l}\text { Glulam bending } \\
\text { strength }\end{array}$ & $0.77 R_{k}$ & 0.15 & $\mathrm{LN}$ & 1.25 \\
\hline $\begin{array}{l}\text { Resistance } \\
\text { model } \\
\text { unc.(timber) }\end{array}$ & $\theta_{R \mathrm{k}}$ & 0.10 & $\mathrm{LN}$ & - \\
\hline $\begin{array}{l}\text { Solid timber } \\
\text { bending strength }\end{array}$ & $0.71 R_{k}$ & 0.20 & $\mathrm{LN}$ & 1.30 \\
\hline Permanent load & $G_{\mathrm{k}}$ & 0.10 & $\mathrm{~N}$ & 1.35 \\
\hline
\end{tabular}

Table 2. Statistical description of structural resistance and loads.

Concerning roof snow load, the same assumptions made in the previous section for the determination of design conversion factor were adopted. In particular, a Gumbel distribution is used to fit annual maxima ground snow load.

A sensitivity analysis to check the influence of $\mathrm{COV}_{\mathrm{g}}$ was performed investigating again 
values between 0.3 and 2 ; for the conversion factors Log-Normal distributions are adopted with the parameters given by the European Snow Load Research Project and reported in Table 1.

The results are illustrated in Fig. 3, 4 and 5 for steel, glulam timber and solid timber structures, respectively. In particular, surfaces for the reliability index $\beta$ variation with the load ratio $\chi$ and the $\mathrm{COV}_{\mathrm{g}}$ are shown for the different wind exposure conditions (sheltered in green, normal in blue and exposed in red).

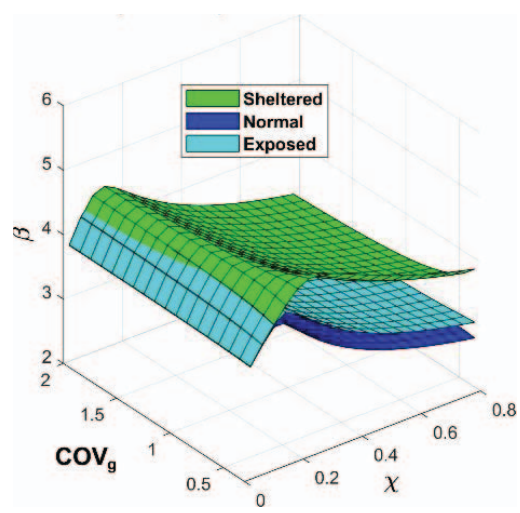

Fig. 3. Yearly reliability index $\beta$ for steel structure, dependence with the load ratio, $\chi$, the coefficient of variation of annual maxima ground snow load $\left(\mathrm{COV}_{\mathrm{g}}\right)$ and the exposure conditions.

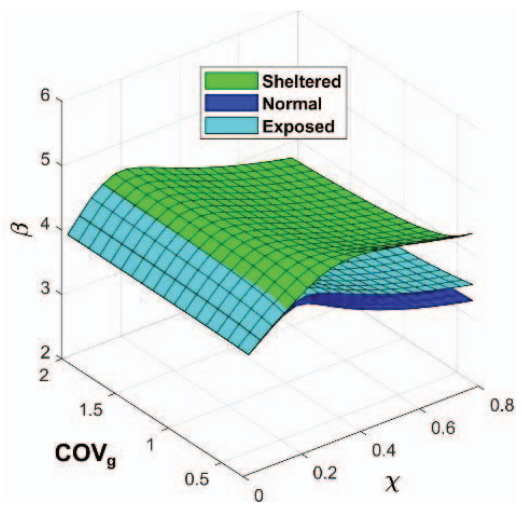

Fig. 4. Yearly reliability index $\beta$ for glulam timber, dependence with the load ratio, $\chi$, the coefficient of variation of annual maxima ground snow load $\left(\mathrm{COV}_{\mathrm{g}}\right)$ and the exposure conditions.

The results confirm an important reduction of the reliability index, more evident for higher load ratios $\chi$ (corresponding to lightweight structures). Obviously, this effect is particularly manifest for steel structures for which, according to EN19931-1 (CEN, 2005), $\gamma_{\mathrm{M}}=1$. Moreover, as it was expected, also site exposure influences the reliability level.

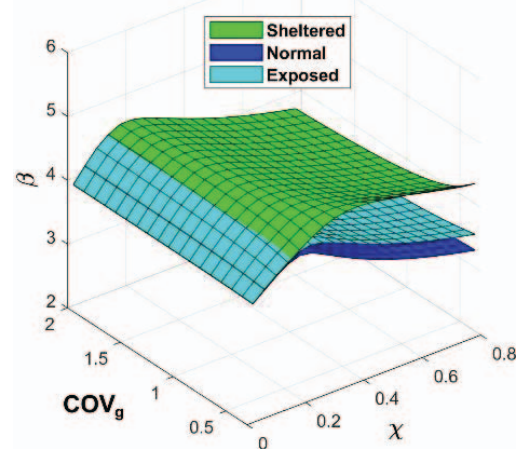

Fig. 5. Yearly reliability index $\beta$ for solid timber, dependence with the load ratio, $\chi$, the coefficient of variation of annual maxima ground snow load $\left(\mathrm{COV}_{\mathrm{g}}\right)$ and the exposure conditions.

Clearly, these reliability index variations, described here, are to be regarded as indicative and cannot be generalized. In fact, it must be underlined that often characteristic ground snow loads given in codes intentionally overestimate the loads resulting from the statistical analysis of data, so introducing some additional safety margin (Croce et al., 2019b). Moreover, the variability of roof snow load is significantly influenced by the uncertainty in the determination of shape coefficient. Looking at Table 1, it results that the Norwegian data, being associated to lower mean values and coefficients of variation of the conversion factor, leads to higher values of the reliability index. Finally, the relevant impact of climate change on ground snow load should be properly assessed in the evaluation of structural reliability (Croce et al., 2019a).

\section{Conclusions}

A methodology to evaluate the characteristic value of roof snow load is discussed, based on the estimation of probability density functions for ground snow loads and conversion factors from ground to roof load.

The results lead to the definition of a design conversion factor, to be used for the evaluation of characteristic roof snow load, which depend on the coefficient of variation of ground snow loads.

Based on available data for flat roofs collected during the European Snow Load Research Project, design conversion factors are derived and compared with the constant values provided by the Eurocode models, in EN1991-1-3:2003. The model in the standard, aiming at a yearly 
probability of exceedance $p=0.02$, appears to be conservative for sheltered conditions $(p=0.015$ per year), slightly unconservative for normal conditions, where the yearly probability of exceedance of the roof snow load are found to be in the interval 0.023-0.054, while it satisfactorily fits the target probability for exposed conditions ( $p=0.019-0.037$ per year).

Finally, structural reliability is assessed for reference steel and timber roof structures designed according to Eurocodes provisions, considering different proportions between variable and permanent loads. The results confirm that lightweight structures are associated to lower reliability levels, also showing the relevant influence of exposure conditions in the reliability analysis, thus leading to the need of further investigations on the definition of stochastic models for conversion factors.

\section{References}

CEN (2002), EN 1990. Eurocode-Basis of Structural Design; Brussels, Belgium.

CEN (2003), EN 1991-1-3. Eurocode 1: Actions on Structures-Part 1-3: General ActionsSnow Loads, Brussels, Belgium.

CEN (2005) EN1993-1-1. Eurocode 3: Design of steel structures - Part 1-1: General rules and rules for buildings, Brussels, Belgium.

Cook N.J. and Mayne J.R. A refined working approach to the assessment of wind loads for equivalent static design. Journal of Wind Engineering and Industrial Aerodynamics, 6 (1980) 125-137.

Croce P., Formichi P., Landi F., Mercogliano P., Bucchigiani E., Dosio A. and Dimova S. (2018a) The snow load in Europe and the climate change. Climate Risk Management 20, 138-154.

Croce P., Formichi P., Landi F. and Marsili F. (2018b). Climate change: Impact on snow loads on structures. Cold Regions Science and Technology 150, 35-50.

Croce P., Formichi P., Landi F. (2019a). Climate Change: Impacts on Climatic Actions and Structural Reliability. Appl. Sci. 2019, 9, 5416.

Croce, P.; Formichi, P.; Landi, F.; Marsili, F. (2019b). Harmonized European ground snow load map: Analysis and comparison of national provisions. Cold Reg. Sci. Technol., $168,102875$.

Ellingwood, B. and O'Rourke M, (1985), Probabilistic models of snow loads on structures, Structural Safety, 2, 291-299.

Gulvanessian, H. \& Holicky, M. (2005). Eurocodes: using reliability analysis to combine action effects. Proceedings of the Institution of Civil Engineers, Structures \& Buildings 158: 243-252.
Holicky, M. (2007). Safety design of lightweight roofs exposed to snow load. Eng. Sci. 58, 5157.

Høibø, H. (1988). Snow load on gable roofsResults from snow load 609 measurements on farm buildings in Norway. First Int. Conf. on Snow Engineering, U.S. Army Corps of Engineers, 95-104.

Høibø, H. (1989). Form factors for snow load on gable roofs: Extending use of snow load data from inland districts to wind exposed areas. Proc. 11th Int. Congress on Agricultural Engineering, Balkema, Rotterdam, Netherlands.

Joint Committee on Structural Safety (JCSS). Probabilistic Model Code 2001.

Kozak D. L., Liel A. B. (2015) Reliability of steel roof structures under snow loads. Structural Safety, 54, 46-56,

Sykora, M. and Holicky, M. (2008) Reliabilitybased design of roofs exposed to a snow load. In Li, J. - Zhao, Y.-G. - Chen, J. (eds.) Reliability Engineering - Proceedings of the International Workshop on Reliability Engineering and Risk Management IWRERM 2008, Tongji University Press, p. 183-188.

O'Rourke, M.J. Roof Snow Loads for Structural Design. Journal of Structural Engineering, Vol.109, 1983, pp.1527-537.

O'Rourke M.J., Redfield R., and von Bradsky P. Uniform snow load on structures. Journal of Structural Division, Vol.108, 1982, pp.27812798.

Sanpaolesi, L. et al. Phase 1 (1998) Final Report to the European Commission, Scientific Support Activity in the Field of Structural Stability of Civil Engineering Works: Snow Loads, Department of Structural Engineering, University of Pisa.

Sanpaolesi, L. et al. Phase 2 (1999) Final Report to the European Commission, Scientific Support Activity in the Field of Structural Stability of Civil Engineering Works: Snow Loads, Department of Structural Engineering, University of Pisa.

Thiis T. K. and O'Rourke M. (2015). Model for Snow Loading on Gable Roofs, Journal of Structural Engineering 141, 1-9. 